Research.

\title{
THE EFFECTS OF CAPITAL, PROFITABILITY, LIQUIDITY UPON THE PREDICTION OF NATIONAL BANK FRAGILITY
}

\author{
Syarief Gerald Prasetya \\ Lecturer at STIE Binaniaga, Bogor
}

\begin{abstract}
An indication of banking crises within 2014 has been identified due to a slowing down of credit development, inappropriate resources, high cost of the funds and an increasing of NPL which have created a pressure on the banking profitability level which is a small value of net profit ratio upon the assets (ROA). Less profit has happened due to a decreasing of new credit distribution as well as an increasing of provision cost refers to credit problem (NPL). Banking sector is quite fragile, it is the result of banking network system either national or international. Early detection upon bank fragility can minize a jeopardy risk of banking sector systematically which is an improper intermediary function of banking. The research aims to discover whether a significant effect of capital, profitability and liquidity has happened upon the prediction of banking crises. Research method has applied associated descriptive and the analysis has applied logistics regression. Result of the research has identified that only probability variable has affected significantly the crises of banking, it is suggested that the banks should have to be more concerned about internal and external factors to improve bank profitability.
\end{abstract}

Keywords: bank sector fragility, capita adequacy ratio, return on assets, non performing loan.

\section{INTRODUCTION}

\section{Background of The Problem}

The development of Indonesia has required an economics stability which will support the government efforts to design a planning and to improve the development at all sectors. Economics stability will ease the government to conduct an evaluation and prediction in designing the development program. One of the requirements to reach an economics stability is an effort to create the stability of monetary condition. Such a condition would be achieved if banking system were fit, it is in a good condition when a bank does not have any problems upon its liquidity. Fit banking sectors will provide a condusive atmosphere in business, nevertheless, lots of banks are very fragile either internal or external condition of the bank refers to domino effects.

In 2015 Bank Info Research Bureau indicated that the profit of national bank had decreased. This decreasing had happened for the last two years and it indicated a banking crises was occured. Few years ago, it indicated 12 banks which had been non performing loan (NPL) which is $>5 \%$, they have to restructure their credit crises. During monetary crises most of the banks in Indonesia had been liquidated refers to monetary crisis in 1997, 11 banks had been liquidated. It happened because they were unable to settle their debts either short term or long term settlement. As a matter of fact the Capital Adequacy Ratio (CAR) had increased from $19.57 \%$ end of 2014 to $20.79 \%$ in April 2015 (LPS, 2015). CAR increasing had happened due to a conversion of operational accountancy profit end of 2014 which is a retained profit of the capital component. The banks were fully aware of such a difficult situation that should have to face in 2015 so that 
the management had made a decision to hold a retained profit in order to increase the capital.

Banking crises happened within 2015 had been indicated due to credit stagnation, unoptimized resources, high cost of the funds and an increasing of NPL had been created a pressure of banking profitability refered to low ratio of net profit upon the assets (ROA). Profit decreasing was happened due to reducing of new credit distribution and increasing of provision cost upon credit problems (NPL). Banks were obliged to settle the credit payment (short term or long term payment) and daily operational payment of the bank. Though, after liquidating the related banks, many banks had minimum assets and they could not settle all their debts. This condition could happen because of bad financial management system and ineffective capital management to create the profit.

The condition of national banking crises had been trigerred by economics crises in Asia which were related to the economics in European countries that had been shocked by financial sectors such as in Yunani. Banking sector is fragile relatively, it happened due to banking system either local or international network. An early detection of bank fragility would be able to minimize a jeopardy risk of banking sectors systematically that could affect inappropriate banking intermediary functions. A stagnation of banking function has affected other sectors, so that, a measurement upon bank sector fragility index should have to be done to anticipate systemics impact. Fragility index is measured based on the level of sufficient capital, liquidity, profitability, market risk and asset quality.

\section{Problems Formulation}

1. Is there any significant effect of the capital happened upon the prediction of national banking crises?

2. Is there any significant effect of the probability happened upon the prediction of national banking crises?

3. Is there any significant effect of the liquidity happened upon the prediction of national banking crises?

\section{Research Objectives}

1. To prove empirically a significant effect of the capital upon the prediction of national banking crises.

2. To prove empirically a significant effect of the probability upon the prediction of national banking crises.

3. To prove empirically a significant effect of the liquidity upon the prediction of national banking crises.

\section{THE LIBRARY REVIEW}

\section{Banking Sector Fragility (BSF)}

Banking Sector Fragility (BSF) is an index to be applied to measure or monitor any changes of fragility banking sector crises. This index is expected to be able to provide further information related to the crises. An empirical index of BSF function has been able to figure out any changes of risk taker behavior of the bank referring to its monthly data. A monthly BSF index has contributed significantly the decision maker (an effort to obtain an early detection upon banking crises). It is usable as supporting method to identify a crisis, eventhough it could not be able to replace completely an event based approach.

The indicators of banking sector fragility according to Bruinshoofd et al. 2008, it is covering banks assets refers to PDB (Bruto Domestic Products), a claim of domestic product of non-finance sector which is deposit, overhead cost, Net interest Margin, deposit ratio, claim of private sector and state sector, domestics credit provided by the bank, banks' reserve on assets ratio, loans index, foreign bank penetration, ratio price of 
foreign assets, and foreign funds. Banking Sector Fragility is negative which is related to banking liquidity and profitability. Referring to the liquidity, ratio of bank's reserve, bank assets, a big ratio is usually indicating a strong banking system, and information of bank deposit is a part of PDB.

\section{Capital}

Capital is an important aspect to evaluate bank condition which is relating to bank solvability. Function of this ratio is to measure a significant capital owned by the bank to support its activity facing a risk, eq, credit offered. Basic core of a company to be able to run its business is its capital. For a new established company, capital is required to start up and run its business. But, for an established company, capital is required to develop its business and to evolve its market. According to the Association of Indonesia Accountancy (IAI) capital is part of the owner's right in a company which is a balance value between assets and debts but it is not the sale value of the company. In a booklet of Indonesia Banking 2014 Financial Services Authority (OJK) described that Basel Committee on Banking Supervisions's (BCBS) has issued a concept of capital design as the standard of bank's capital calculation which is more sensitive recognized as Basel II. In general Basel II design consists of three pillars:

1. A bank is obliged to have an adequate minimal capital be able to manage it to cover all the risk encountered refers to an exposure risk of a credit, market and operational. Bank capitalization ratio or a comparison between regulatory capital and ATMR should not less than $8 \%$.

2. Bank supervisory review process is obliged to have the process of adequate capital evaluation overall related to the profile of risk and strategy to manage the capitalization level.

3. Market disciplines and details of the minimum limitation that can be disclosed to the public.

Based on the Circular Letter of the Bank of Indonesia No. 13/24/DPNP/2011 regarding an obligation to provide a minimum capital for public banks which is in relation with an evaluation of capital adequacy, a bank has to identify the capital adequacy related to the risk profile of bank. The bigger risk of a bank is dealing with, the bigger capital should have to be provided to anticipate the related risk. In connection with an evaluation, a bank should have to consider its level, trend, structure and stability of its capitalization by being concerned in the performance of the group as well as an adequate management of bank capitalization.

\section{Profitability}

One of the measurements to recognize the effectiveness and efficiency of a company is its profitability, the higher profitability a company got, the more effective and efficient a company management would be (Sofyan, 2003). Performance measurement is to figure out the result of strategic decision, operational and financial of the company. In order to measure a company performance, profitability ratio has been applied to measure the management effectiveness based on its sales revenue and return on investment as well as development ratio measuring the capability of the company to keep its economical position refers to the economics and industries development. The measurement of the management capability to catch the market value more than cost spending (Wahyuni, 2012).

\section{Liquidity}

The Regulation of Bank of Indonesia No. 10/1/PBI/2004 Chapter 4 described liquidity is a risk caused by the unability of the bank to settle its debts which was due date refers to cash flow, and/or high quality of liquid assets without interfering the activity and financial condition of the bank. Liquidity is happened due to the unavailability of the bank

Syarief Gerald Prasetya: The Effects of Capital, Profitability, Liquidity upon The Prediction of National Bank Fragility 
to liquid the asset without any material discount offered since there is not any active market or there is a market disturbance.

\section{RESEARCH METHOD}

\section{Research Method}

Method of this research has applied associative descriptive method. Descriptive research aims to figure out systematically, factually and accurately the connection of inter phenomena studied. An associative research is to identify the effect of independent variables upon dependent variables.

\section{Population and Sampling Technique}

a. Population

The population of this research is Bank Umum Nasional (National Public Bank) which has been 'go public' during the observation periode of 2010-2014.

b. Sample

Technique has applied judgement sampling technique, samples has been compiled due to a certain consideration. Therefore, sampling has been compiled based on the following criteria:

1) Bank Umum National which has been 'go public' for the periode of 2010 to 2014.

2) Banks which have fragility level refers to the index value is less than -0.5 or between 0 to -0.5

\section{Data Compiling Technique}

Data compiled thru library research which is quantitative data obtained from the Research Bureau of Info Bank refers to banking financial reports that have been audited during 2010-2014.

\section{Research Variables}

a. Dependent variable is a fragility index of banking sector, banking crises has been determined by applying banking sector fragility (BSF) index as follows:

$$
\text { BSF3 }=\frac{\left(\frac{C P S_{t}-\mu_{c p s}}{\sigma_{c p s}}\right)+\left(\frac{F L_{t}-\mu_{f l}}{\sigma_{f l}}\right)+\left(\frac{D E P_{t}-\mu_{d s p}}{\sigma_{d e p}}\right)}{3}
$$

- when an index value is between $-0.5<\mathrm{BSFI}<0=$ banking sector is considered quite fragile.

when BSFI $<-0.5=$ the most fragile, so that $<0$ is not good and indicated crises, $>0$ is good refers to the following equations:

$$
\begin{aligned}
& C P S_{t}=\left[\frac{\left(L C P S_{t}-L C P S_{t-12}\right)}{L C P S_{t-12}}\right] \\
& F L_{t}=\left[\frac{\left(L F L_{t}-L F L_{t-12}\right)}{L F L_{t-12}}\right] \\
& D E P_{t}=\left[\frac{\left(L D E P_{t}-L D E P_{t-12}\right)}{L C P S_{t-12}}\right]
\end{aligned}
$$

Descriptions

LCPS = Loans at private sector, credit distributed. 


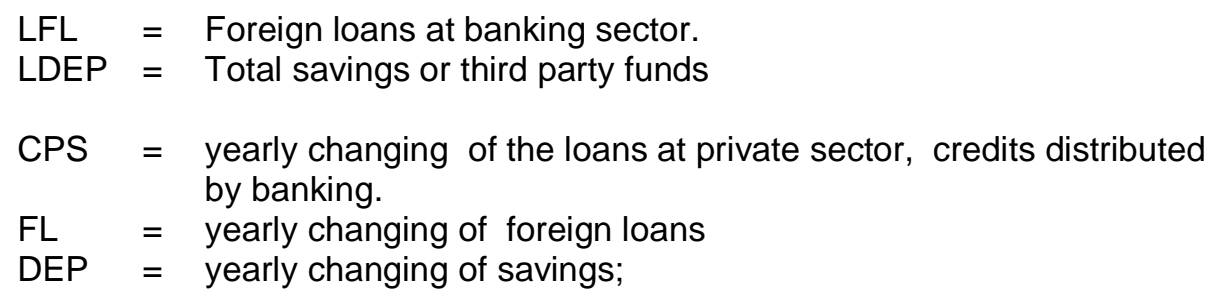

$\mu$ dan $\sigma-=\mu$ and $\sigma-=$ each means and standard deviation. (Kibritcioglu, 2002)

b. Independent variable is capital ratio calculated using Capital Adequacy Ratio (CAR) proxy

$$
\mathrm{CAR}=\frac{\text { Bank capital }}{\text { Risk considerated assets }} \quad \mathrm{x}_{100 \%}
$$

(source: Enclosures of SE BI No.3/30/DPNP/2001)

c. Independent variable of profitability applying Return On Assets (ROA) proxy.

$$
\mathrm{ROA}=\frac{\text { Profit before tax }}{\text { Average of total assets }} \times 100 \%
$$

(Source : Enclosures of SE BI 13/24/DPNP/2011)

d. Independent variable of liquidity applying Non Performing Loan (NPL) proxy

$$
\text { NPL }=\frac{\text { credit crises }}{\text { Total of the credit }} \times 100 \%
$$

(Source : SE BI 13/24/DPNP/2011)

\section{Data Analysis Technique}

a. Introduction analysis has applied descriptive statistics which is describing the data of each variable partially. Descriptive statistics has applied an average, frequency and percentage.

b. Logistics Regression Analysis

Logistics regression would be applied if a dependent variable were having dicotom scale and data normality assumption of its independent variable were not required. Statistics analysis has applied software Statistical Product and Service Solution (SPSS) version 20. The equation of an estimated regression model as follows;

$$
\begin{aligned}
& \text { BSF = } \alpha-\beta \text { CAR }-\beta \text { ROA }+\beta \text { NPL }+ \text { e } \\
& \text { Where : } \quad \begin{array}{ll}
\text { BSF } & =\text { (Prediction Bank fragility) } \\
\alpha & =\text { Konstanta } \\
\beta & =\text { Coefficient of regression model } \\
\text { CAR } & =\text { Capital Adequacy Ratio } \\
\text { ROA } & =\text { Return On Assets } \\
\text { NPL } & =\text { Non Performing Loan } \\
\text { e } & =\text { Error }
\end{array}
\end{aligned}
$$


c. Test of overall model fit

Overall model fit is a measurement to identify an overall model which is fit hypothesis, refers to $\alpha=5 \%$, hypothesis test is as follows;

- $\mathrm{H}_{0}$ : if the value is $-2 \mathrm{Log} \mathrm{L}<0.05$ the model is hypothized fit.

- $\mathrm{H}_{1}$ : if the value is $-2 \mathrm{Log} L>0.05$ the model is hypothesized unfit.

d. Fit Test of regression model

1) Fit test of Logistics regression model has applied Hosmer and Lemeshow Goodness of Fit Test. Test criteria refers to Ghozali descriptions (2009) as follows:

2) When the statistics value of Hosmer and Lemeshow Goodness of Fit Test is equal or less than 0.05 , so that $\mathrm{H}_{0}$ is rejected and the model is considered unfit. It explains that there is a significant discrepancy of the model as it can not predict its observation value.

3) When the statistics value of Hosmer and Lemeshow Goodness of Fit Test is more than 0.05 , so that $\mathrm{H}_{0}$ is accepted and the model is considered fit, it means that the model can predict its observation value.

e. Determinant Coefficient (Nagelkerke's R Square)

The value of determinant coefficient at the logistics regression model has been indicated by the value of Nagelkerke's R Square to figure out how big the model applied enables describing a dependent variable using independent variables, Ghozali (2009).

f. Omnibus Test of Model Coefficient

This model is to evaluate the significance level of capital, probability and liquidity variables overall which is affecting significantly banking crises. A simultaneous logistics regression test can be done refers to the table of Omnibus Test of Model Coefficient.

g. Wald Test

This test has been conducted to figure out how big the effect of independent variable to dependent variable by indicating the significance level of each variable. $W$ quadrate value is in compliance with the distribution of Chisquare which is $d f=1$. When $W k \geq X^{2}(\alpha, 1)$ or $p$-value $\leq \alpha$ so that $H_{0}$ is rejected and $\mathrm{H}_{1}$ is accepted refers to the following testing criteria:

1) When wald significance $<0.05, \mathrm{H}_{0}$ is accepted and $\mathrm{H}_{1}$ is rejected, so that independent variable has affected significantly dependent variable.

2) When wald significance $\geq 0.05, H_{0}$ is accepted and $H_{1}$ is rejected, so that independent variable has affected significantly dependent variable.

Hypothesis of this research are as follows:

1) $H_{0}:$ There is not any significant effects of the capital upon the prediction of banking crises.

$\mathrm{H}_{1}$ : There is a significant effect of the capital upon the prediction of banking crises.

2) $H_{0}:$ There is not a significant effect of profitability upon the prediction of banking crises.

$\mathrm{H}_{1}$ : There is a significant effect of profitability upon the prediction of banking crises.

3) $H_{0}$ : There is not any significant effect of liquidity upon the prediction of banking crises.

$\mathrm{H}_{1}$ : There is a significant effect of liquidity upon the prediction of banking crises.

\section{RESULT OF RESEARCH AND THE DESCRIPTION}

Based on the data, 37 banks are obtained. In the previous analysis 31 banks have been classified banks crises and as the samples of this research. Data are analyzed in the quarterly intervals.

Syarief Gerald Prasetya: The Effects of Capital, Profitability, Liquidity upon The Prediction of National Bank Fragility 
1. Description of capital data

Proxy to measure the capitalization is CAR value which is the capital of a bank compared with the assets according to the risk. In order to understand CAR description during the periode of the research, it is described on the following table:

Table 1.

Descriptive Statistics of CAR Variable

\begin{tabular}{|l|r|}
\hline & \multicolumn{2}{|c|}{ CAR } \\
\hline $\mathrm{N} \quad$ Valid & 31 \\
& Missing \\
Mean & 26,9988 \\
Std. Error of Mean & 3,23198 \\
Median & 16,0950 \\
Mode & $14,07^{\mathrm{a}}$ \\
Minimum & $-17,63$ \\
Maximum & 1260,84 \\
Sum & 16739,23 \\
Percentiles (75) & 21,3350 \\
\hline
\end{tabular}

Source : data evaluated

Based on the aforementioned table, it has identified means value of 26.9988 interpreting that average CAR of each bank within 3 months is 26.9988. Mode value has indicated that those 31 banks mostly have CAR value of 14.07 . Nevertheless $75 \%$ of 31 banks have CAR value less than 21.3350 . It explains that about $25 \%$ of those banks have CAR value more than 21.3350.

2. Description the data of profit

In order to identify the data of profit, ROA proxy has been applied. ROA is a comparison value between profit before tax and the average of the total assets. ROA value is described on the following table:

Table 2

Statistics Descriptive of ROA variable

\begin{tabular}{|l|r|}
\hline & \multicolumn{2}{|c|}{ ROA } \\
\hline N $\quad$ Valid & 31 \\
Mean $\quad$ Missing & 0 \\
Std. Error of Mean & 20,9155 \\
Median &, 24708 \\
Mode & 21,4740 \\
Minimum & $21,71^{\text {a }}$ \\
Maximum & $-98,18$ \\
Sum & 30,36 \\
Percentiles (75) & 12967,61 \\
Source : data evaluated & 22,2488 \\
\hline
\end{tabular}

Syarief Gerald Prasetya: The Effects of Capital, Profitability, Liquidity upon The Prediction of National Bank Fragility 
On the table 2 aforementionned, ROA means is 20.9155 indicating the average of ROA of each bank within three (3) months is 20.9155. Mode value has indicated that those 31 banks mostly are having ROA value of 21.71 . Nevertheless, $75 \%$ of 31 banks have ROA value less than 22.2488 . Therefore, it has explained that $25 \%$ of those banks have ROA value more than 22.2488.

3. Description the data of Liquidity

Liquidity has applied NPL proxy which is the comparison between the credit crises and the credit total distributed by the bank. In order to indicate NPL value, the following table 3 has explained it:

Table 3

Statistics Descriptive of NPL variable

\begin{tabular}{|l|r|}
\hline & \multicolumn{1}{|c|}{ NPL } \\
\hline N & Valid \\
Mean & 31 \\
Std. Error of Mean & 0 \\
Median & 2,9512 \\
Mode &, 19885 \\
Minimum & 2,0700 \\
Maximum & 0,12 \\
Sum & 0,08 \\
Percentiles (75) & 51,00 \\
\hline
\end{tabular}

Source : data evaluated

NPL means value is 2.9512 interpreting that the average of NPL of each bank within 3 months is 2.9512 . Mode value has indicated that those 31 banks mostly are having NPL value of 0.12 . Nevertheless, $75 \%$ of 31 banks have NPL value less than 3.2175. So that, $25 \%$ of the banks have NPL value more than 3.2175 .

4. Description of the data of Banks Crises

In order to measure a bank in crises, proxy index of BSF of each bank within the periode of the research has been applied. Bank crises is the condition of a bank that is suffering from the risk of bankcruptcy due to a negative assets value. The following table has described BSF index:

Table 4

Statistics Descriptive of BSF variable

\begin{tabular}{|l|r|}
\hline & \multicolumn{1}{|c|}{ BSF } \\
\hline N $\quad$ Valid & 620 \\
Mean & 0 \\
Std. Error of Mean &,- 2827 \\
Median &, 00547 \\
Mode &,- 3000 \\
Minimum &,- 37 \\
\hline
\end{tabular}

Syarief Gerald Prasetya: The Effects of Capital, Profitability, Liquidity upon The Prediction of National Bank Fragility 


\begin{tabular}{|l|r|}
\hline & \multicolumn{1}{|c|}{ BSF } \\
\hline Maximum &,- 14 \\
Sum & $-175,26$ \\
Percentiles (75) &,- 2000 \\
\hline
\end{tabular}

Source : data evaluated

Based on the table aforementioned, it has identified the means value of $\mathrm{Rp}$ 9,942.2333 indicating an average value of BSF of each bank within 3 months is 0.2827 . Mode value has described that most of the banks have BSF value of -0.370 on the quarterly intervals during the research periode. $75 \%$ of the banks have BSF value less than -0.200 .

\section{Result of Data Analysis}

Based on the result of the data evaluated which has applied SPSS, it has indicated the test result of overall model fit as follows:

Table 5

Result of Analysis of Omnibus Tests of Model Coefficients

\begin{tabular}{|ll|r|r|r|}
\hline & & Chi-square & \multicolumn{1}{|c|}{ Df } & \multicolumn{1}{c|}{ Sig. } \\
\hline & Step & 42,356 & 10 &, 000 \\
Step 1 & Block & 42,356 & 10 &, 000 \\
& Model & 42,356 & 10 &, 000 \\
\hline
\end{tabular}

Source : data evaluated

Based on the test result of overall model fit, it has indicated a decreasing of -2 log likelihood with the chi-square value of 42.356 and sig value 0.000 which is less than 0.05 , it explains that the model of this research is applicable.

This model is determined fit when p-value Hosmes and Lemeshow Goodness of Fit Test is more than 0.05 . In order to test it the following table has described the following:

Table 6

Result of Analysis of Hosmer and Lemeshow Test

\begin{tabular}{|l|r|r|r|}
\hline Step & Chi-square & Df & Sig. \\
\hline 1 & 3,270 & 8 &, 742 \\
\hline
\end{tabular}

Source : data evaluated

Result of data analysis has indicated significant value ( $p$-value) is 0.742 which is more than 0.05 . Therefore, this model is able to predict an observation value or this model is acceptable because it is fit with the observation data. The determinant coefficient value is described on the table 7 as follows:

Table 7

Result of Analysis of Determinant Coefficient

\begin{tabular}{|l|r|r|r|}
\hline Step & -2 Log likelihood & $\begin{array}{c}\text { Cox \& Snell R } \\
\text { Square }\end{array}$ & $\begin{array}{c}\text { Nagelkerke R } \\
\text { Square }\end{array}$ \\
\hline 1 & $188,902^{\mathrm{a}}$ &, 074 &, 186 \\
\hline
\end{tabular}

Soure : data evaluated

Syarief Gerald Prasetya: The Effects of Capital, Profitability, Liquidity upon The Prediction of National Bank Fragility 
Based on the result aforementioned, value of nagelkerke $R$ square is 0.186 , it explains that the variation of dependent variable (banking crises) can be figured out by the independent variable which is $18.6 \%$. And the remaining of $81.4 \%$ can be described by other variables which are not included within this research. The exact prediction model can be studied on the following table 8 .

Table 8

Result of Analysis of Classification Table

\begin{tabular}{|l|ll|r|r|r|}
\hline \multirow{2}{*}{} & \multirow{2}{*}{ Observed } & \multicolumn{3}{|c|}{ Predicted } \\
\cline { 3 - 5 } & & \multicolumn{3}{|c|}{ BSF } & \multicolumn{1}{c|}{$\begin{array}{c}\text { Percentage } \\
\text { Correct }\end{array}$} \\
\cline { 3 - 6 } & &, 00 & 1,00 & 2,5 \\
\multirow{2}{*}{ Step 1 } & BSF &, 00 & 1 & 39 & 99,5 \\
& Overall Percentage & & 3 & 577 & 87,4 \\
\hline
\end{tabular}

Source : data evaluated

On the table 6 , it has determined that the value of hosmer and lemeshow goodness-of-fit test is 3.270 and the significance of probability is 0.742 which value is more than 0.05 and the value of overall percentage 87.4 on table 8 explaining that the model is applicable and in compliane with the observation data with the level of prediction accuracy overall is $87.4 \%$.

In order to identify the effect of independent variable upon the dependent variable partly can be described on the following table 9 .

Table 9

Result of Wald Analysis

\begin{tabular}{|c|c|c|c|c|c|c|c|}
\hline & & $B$ & S.E. & Wald & df & Sig. & $\operatorname{Exp}(B)$ \\
\hline \multirow{4}{*}{ Step $1^{a}$} & Car & ,002 & ,014 & ,028 & 1 & ,868 & 1,002 \\
\hline & Roa &,- 067 & 027 & 7,66 & 1 & ,027 & 807 \\
\hline & $\mathrm{Npl}$ & 082 & , 020 & 3,151 & 1 & 118 & 978 \\
\hline & Constant & 7,530 & 1,889 & 17,555 & 1 & ,000 & 11236,176 \\
\hline
\end{tabular}

Source : data evaluated

On the table 9 aforementioned, it has indicated CAR variable has not affected the prediction of banking crises since the significant value 0.868 which is more than 0.05 . Profitability variable (ROA) has been affecting the banking crises since the significant value 0.027 which is more than 0.05 . Liquidity value (NPL) has not affected the prediction of banking crises since the significant value 0.118 which is more than 0.05 .

Therefore, the regression equations is as follows:

$$
\mathrm{BSF}=7,530+0,002 \mathrm{CAR}-0,067 \mathrm{ROA}+0,082 \mathrm{NPL}+\mathrm{e}
$$

\section{Description}

1. The effect of capital upon the banking crises

The result of the research has indicated that the capital has not affected significantly the prediction of banking crises during the periode of 2011 to 2014 . The capital in this research has been determined by CAR indicating a decreasing of banking assets due to some losses happened because of banking assets risks. CAR has not affected significantly banking prediction which is a signal indicating that during the research period, banking has followed the regulation of the Bank of 
Indonesia refers to minimum capital $8 \%$, nevertheless CAR ratio is $26.99 \%$ which is more than CAR determined by $\mathrm{BI}$. This research has been in compliance with the previous research done by Mulyaningrum (2008) determined that CAR did not affect banking crises since Bank Umum Nasional has respected the regulation about a minimum capital determined by BI.

2. The effect of probability upon the banking crises.

The result of this research has indicated that profitability has been affecting significantly and has had a negative relationship upon the prediction of banking crises. Probability has applied Return On Assets (ROA) ratio. At average ROA value of the banks being the samples is $20.91 \%$. It explains that most of the banks as the samples have had big ROA value. The banks having big ROA have been indicating that the related banks have achieved a good financial performance since they have enabled to manage all the assets and to get an appropriate profit, but the banks having low ROA have been indicating that the related banks have their own profitability.

This research is in compliance with the research done by Pratama Rendra (2015) regarding an analysis upon the effect of financial ratio to predict the condition of financial distress of public banks. Based on the result of the analysis, the probability has affected significantly the prediction of condition of financial distress.

3. The effect of liquidity upon banking crises.

Based on the result of analysis, NPL of the banks at average is $2.9512 \%$. This ratio has indicated most of the banks being the samples of this research has had low NPL value, So that, it can be determined that the samples at average have had good NPL indicating that they do not have any effect to the prediction of banking crises. The national banks have implemented a very selective principle to distribute the credit to the people which is a potential risk of the credit can be minimized. The result of the research is in compliance with the study of Wahyudi and Sutapa (2010) declared that a liquidity of a bank has not affected the prediction of banking crises. It happened due to each bank has implemented a very selective principle to manage its liquidity. This condition happened due to the economical crises experience in Indonesia in 1996 which had educated banking industries to be more alert to manage their liquid assets. However, the government has monitored obviously banking industries, especially the one related with the minimum backup to be fulfilled by any bank so that the banks could implement the selective principles.

\section{CONCLUSIONS AND SUGGESTIONS}

\section{Conclusions}

1. The Capital did not affect significantly the prediction of banking crises in Indonesia, so that the capital can not used as the tools to predict banking crises in Indonesia.

2. Probability has affected significantly the prediction of banking crises, so that the probability can be used as the tools to predict banking crises in Indonesia.

3. Liquidity has not affected significantly banking crises, so that liquidity can be used as the tools to predict banking crises in Indonesia.

\section{Suggestions}

1. Banks should have to be more aware of the probability level since the probability has affected significantly the prediction of banking in Indonesia.

2. Further research is required to include the internal variables refer to ROE, NIM, BOPO, LDR and other macro variables affecting the prediction of banking crises. 


\section{REFERENCES}

Bank Indonesia, 2003. "Surat Edaran Bank Indonesia Nomor 5/21/DPNP tentang Pedoman Standar Penerapan Manajemen Risiko Bank Umum" 29 September 2003. http://www.bi.go.id.

, 2004. "Peraturan Bank Indonesia Nomor10/1/PBI/2004 Pasal 4 tentang Ketentuan Umum Sistem Penilaian Tingkat Kesehatan Bank Umum" http://www.bi.go.id.

2007. "Peraturan Bank Indonesia Nomor 9/13/PBI/2007 tentang Kewajiban Penyediaan Modal Minimum Bank Umum" 1 November 2007 http://www.bi.go.id.

2013 Peraturan Bank Indonesia No 15/12/PBI/2013 tentang kewajiban Penyediaan Modal Minimum Bank Umum Modal. http://www.bi.go.id.

2011. "Surat Edaran Bank Indonesia No.13/24/DPNP Perihal Penilaian Tingkat Kesehatan Bank Umum" http://www.bi.go.id.

,2012 Peraturan Bank Indonesia No14/26/PBI/2012 tentang Kegiatan Usaha dan Jaringan Kantor Berdasarkan Modal Inti Bank. http://www.bi.go.id.

Budiarti, 2014. Identifikasi Modal, Profitabilitas, Likuiditas, Pdb, Inflasi dan Nilai Tukar Sebagai Prediksi Krisis Perbankan di Indonesia. Jurnal Mahasiswa Teknologi Pendidikan.Jurnal IImu Manajemen Vol 2 Nomor 4

Chandrarin, G dan Tearney, M,G. 2000. The Effect of Reporting of Exchange Rate Losses on The Stock Market Reaction, Jurnal Riset Akuntansi Indonesia, Vol. 3 , No. 1, Januari 2000.

Degryse, et al., 2013 Determinants of Banking System Fragility A RegionaPerspective Working Paper Series NO 156 / july 2013.

Ghozali, Imam, 2009. Aplikasi Analisis Multivariate dengan Program SPSS, Edisi Keempat, Penerbit Universitas Diponegoro.

Hadad, M. D., Santoso, W., Sarwedi, Sukarno, H. 2004. Model Prediksi Kepailitan Bank Umum di Indonesia. Research Paper Direktorat Penelitian dan perbankan. http://bi.go.id

Harahap, Siti Romida., 2013 Deteksi Dini Krisis Nilai Tukar Indonesia: Identifikasi Variabel Makro Ekonomi Tahun 1995-2011. Economics Development Analysis Journal http://journal.unnes.ac.id/sju/index.php.

Himawan, Adhitya. "Riset Info Bank: 65 Bank Berpredikat Sangat Bagus" 3 Juli 2015. http://keuangan.kontan.co.id.https://www.bps.go.id

Hosmer, D.W., and Lemeshow, S. 1989. Applied Logistic Regression. John Willey, New York.

Jagtiani, Julapa, Kolari James, Catherine Lemieux, and Hwan Shin. 2003. Early Warning Models for Bank Supervision: Simpler Could Be Better.Federal Reserve Bank of Chicago Economic Perspectives 27(3): 49-60.

Kajian Stabilitas Keuangan Bank Indonesia, 2003.http://www.bi.go.id.

Syarief Gerald Prasetya: The Effects of Capital, Profitability, Liquidity upon The Prediction of National Bank Fragility 
Kanya Prasidh, Diana. 2015 Dampak Nilai Tukar dan Risk-Based Bank Rating terhadap Prediksi Kondisi Perbankan Indonesia (Studi pada Bank Umum Swasta Nasional Go Public Tahun 2009-2013) Universitas Brawijaya. Malang.

Karnoto, Mohammad, 2016. "Ketegangan Baru Setelah Laba Bank Turun" 19 January 2016. http://infobanknews.com.

Kibritcioglu, 2002 Excessive Risk Talking, Banking Sector Fragility And Banking Crises http://www.business.uiuc.edu/Working_Papers/papers/02-0114.pdf

Musdholifah dan Tony, 2007. Pengaruh Variabel Makroekonomi terhadap Indeks Harga Saham Gabungan di Bursa Efek Jakarta. Jurnal Aplikasi Manajemen Vol.5 No.1

Mulyaningrum, Penny. 2008. Analisis Rasio Keuangan Sebagai Indikator Prediksi Kebangkrutan Bank di Indonesia. Thesis S2 Magister Akuntansi Universitas Diponegoro.

Otoritas Jasa Keuangan, 2014. "Booklet perbankan Indonesia 2014 Otoritas Jasa Keuangan Edisi 1 Maret 2014" www.ojk.go.id

Simorangkir, Iskandar dan Suseno. 2004. Sistem dan Kebijakan Nilai Tukar, Seri Kebanksentralan No12.Jakarta: Pusat Pendidikan dan Studi Kebanksentralan Bank Indonesia (PPSK BI).

Suteja, J dan Ginting G, 2014. Determinan Profitabilitas Bank: Suatu Studi pada Bank yang Terdaftar di BEl.Trikonomika Volume 13, No. 1, Juni 2014, Hal. 62-77.

Syofyan, 2003, "Keputusan "Go Public" dan Hubungannya dengan Kinerja Bank- Bank Swasta di Indonesia", Jurnal Media Riset dan Manajemen. Vol. 3, No. 1, April 2003.

Utomo, Andri Priyo, 2008. Pengaruh Non Performing Loan (NPL) terhadap Kinerja Keuangan Berdasarkan Rasio Likuiditas, Rasio Solvabilitas dan Rasio Probabilitas Pada PT Bank Mandiri (Persero) TBK. Pasca Sarjana Universitas Gunadarma. Jakarta.

Vries, 2005. The Simple Economics of Bank Fragility. Journal of Banking \& Finance 29 (2005) 803-825 Tinbergen Instituut, Erasmus Universiteit Rotterdam, Rotterdam. 
The Accounting Journal of BINANIAGA Vol. 02, No. 01, 2017

PISSN: $2527-4309$

EISSN: $2580-1481$

This page intentionally be emptied.

Syarief Gerald Prasetya: The Effects of Capital, Profitability, Liquidity upon The Prediction of National Bank Fragility

Page : 72 